\title{
On the Translation of "pride" in Pride and Prejudice
}

\author{
LI Xiu-li \\ China University of Political Science and Law, Beijing, China
}

\begin{abstract}
Being the most important word in Pride and Prejudice, "pride" occurs so many times in the novel. The paper mainly examines seven translators' renditions of two dialogues in the novel and points out that the varied renderings of "pride" in different places of the novel by each of the translators ruin the cohesive and coherent texts. These renderings range from being derogatory to neutral and to commendatory: 傲慢, 高傲, 骄傲, 自尊, and 尊 严. The paper argues that three factors are likely to account for the wrong renderings. Firstly, the Chinese title of the novel, though looking perfect with 傲慢 rhyming nicely with 偏见, may have served as a blindfold, rendering the translators oblivious of their evident mistakes. Secondly, the Chinese translators failed to obtain an insightful interpretation of Darcy's pride and the wrong renderings blur the distinction between Darcy's pride and Lady Catherine's arrogance or insolence. Thirdly, the coherent and narrative functions of repetition were not fully valued by the translators of the novel. The paper contends that the rendering of "pride" as 傲慢 is very often inappropriate. 傲慢 is a strong critique that refers to a person's overbearing and disrespectful attitude or behavior, whereas "pride" used to depict Darcy carries a less derogatory connotation. In addition, Darcy's pride has two parts. Externally his proud manners can be "repulsive" to other people while internally his pride relates more to his opinion of himself. The paper then suggests that "pride" be rendered as 骄傲 all the way through the whole novel.

Keywords: pride, Pride and Prejudice, repetition, translation, coherence
\end{abstract}

\section{Introduction}

Jane Austen's novel Pride and Prejudice has always been very popular among Chinese readers and scholars, and a large amount of literature can be found on studies of English-Chinese translation of the novel. However, little work has been done on the translation of the word "pride" in the novel. After a careful comparative study of the novel in its original and Chinese form, it has become clear to me that the word "pride" has caused big problems for Chinese translators. Being the most important word in Pride and Prejudice, "pride" occurs a great number of times in the novel but is rendered differently in different places of the novel, even within one single conversation.

The functions of repetition have been well studied by scholars at every level of discourse from phonological elements to theme and to genre and form. Anderson (1994) and Kirby (2009) examine the narrative functions of repetition in the Bible. Halliday and Hason (2001), HU Zhuang-lin (1984), ZHANG De-lu and LIU Ru-shan (2003), and ZHU Yong-sheng, ZHENG Li-xin, and MIAO Xing-wei (2001) analyze how repeated words help to make a cohesive or coherent text. Studies have also been done by Chinese scholars on the translation of repeated words, but some of them are not valid. JING Su-rong (2010) examines two frequently repeated words "innovation" and "time" in Bacon's Of Innovation and points out that these two

LI Xiu-li, Associate Professor, M.A., School of Foreign Languages, China University of Political Science and Law. 
words have the rhetorical function of highlighting the theme of the prose and each of them should have been rendered as one Chinese equivalent rather than several in each of the four Chinese versions examined in her paper. JING's analysis is valid, but when it comes to the translation of the repeated word "pride" in Pride and Prejudice, more detailed and comprehensive work needs to be done. ZHOU Tian (2007) argues that flexibility is allowed on certain occasions though theoretically repeated words should be kept the same way in a translated work as it is in the original. ZHOU illustrates her points by saying that in the conversation about Darcy's pride between Elizabeth and her friend and family "pride" shall be rendered as the derogatory 傲慢 (arrogance) when uttered by Mrs. Bennet and the neutral 骄傲 (pride) when uttered by Miss Lucas. ZHOU's argument is that Mrs. Bennet and Miss Lucas have very different attitudes towards Darcy. This paper will explain why ZHOU's analysis is not compelling at all.

In the following parts of the paper, two significant examples of wrong renderings of "pride" will be showcased. These examples will be taken from seven Chinese versions of the novel published in Mainland China and Taiwan over a period of more than 50 years from 1955 to 2011. The Chinese versions of the novel are the works of WANG Ke-yi, ZHANG Ling and ZHANG Yang, SUN Zhi-li, FANG Hua-wen, LIU Pei-fang and DENG Sheng-ming, DONG Liu, and LE Xuan. It needs to be mentioned that Wang's version is the earliest version and came out in 1955. The possible causes of the mistaken renderings will then be analyzed. Finally a better rendering of "pride" will be proposed.

\section{Instances of Wrong Renderings of "pride"}

Pride is a character trait, "a very common failing" (to quote Mary, one of the daughters of Mr. and Mrs. Bennet). The word "pride" is used in the novel mainly to depict Darcy, though it is sometimes used to describe Mr. Collins (who is "a mixture of pride and obsequiousness") or Elizabeth (who makes the utterance "I, who have prided myself on my discernment"). There are a great number of instances in the Chinese versions of the novel where "pride" is mistakenly rendered and the paper illustrates the mistakes using two most significant dialogues regarding Darcy's pride. The first example is taken from the dialogue between Elizabeth and Wickham about Darcy's pride in Chapter 16, volume 1 of the novel, and the second one from the dialogue between Elizabeth and her friend and family in Chapter 4, volume 1. To save space, for each dialogue only one Chinese rendition is fully presented, and the different renderings of "pride" in the seven Chinese versions are shown in Table 1 and Table 2. (The underscores and superscripts in the examples are mine.) See dialogue 1 and its Chinese renditions below.

"How strange!" cried Elizabeth. "How abominable! - I wonder that the very pride ${ }^{1}$ of this Mr. Darcy has not made him just to you! - If from no better motive, that he should not have been too proud ${ }^{2}$ to be dishonest, — for dishonesty I must call it".

"It is wonderful," — replied Wickham, — "for almost all his actions may be traced to pride ${ }^{3}$; — and pride ${ }^{4}$ has often been his best friend. $\underline{\mathrm{It}}^{5}$ has connected him nearer with virtue than any other feeling. But we are none of us consistent; and in his behaviour to me, there were stronger impulses even than pride ${ }^{6 \%}$.

"Can such abominable pride ${ }^{7}$ as his, have ever done him good?"

"Yes. It has often led him to be liberal and generous, — to give his money freely, to display hospitality, to assist his

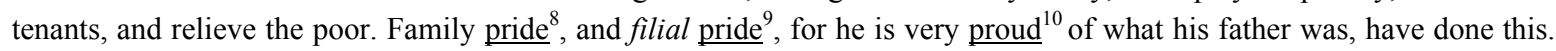
Not to appear to disgrace his family, to degenerate from the popular qualities, or lose the influence of the Pemberley House, is a powerful motive. He has also brotherly pride $^{11}$, which with some brotherly affection, makes him a very kind and careful guardian of his sister; and you will hear him generally cried up as the most attentive and best of brothers". (Austen, 2003, p. 67) 
伊丽莎白叫道: “多奇怪! 多可恶! 我真不明白, 这位达西先生既然这样有自尊心 ${ }^{1}$, 怎么又这样亏待你! 要是没 有别的更好的理由, 那么, 他既是这么骄做 ${ }^{2}$, 就应该不屑于这样阴险……我一定要说是阴险”。

“的确稀奇”, 韦翰回答道: “归根结底来说, 差不多他的一切行动都是出于傲慢, 傲慢4成了他最要好的朋友。照 说他既然傲慢 ${ }^{5}$, 就应该最讲求道德。可是人总免不了有自相矛盾的地方，他对待我就是意气用事多于傲慢 ${ }^{6}$ ”。

“象他这种可恶的傲慢，对他自己有什么好处?”

“有好处：常常使他做起人来慷慨豪爽......花钱不吝啬, 待人殷勤, 资助佃户, 救济贫苦人。他所以会这样, 都 是因为门第祖先使他感到骄傲, 他对于他父亲的为人也很引为骄傲 ${ }^{10}$ 。他主要就是为了不要有辱家声, 有违众望, 不要失掉彭伯里族的声势。他还具有做哥哥身份的骄傲 ${ }^{11}$, 这种骄傲, 再加上一些手足的情份, 使他成了他妹妹的 亲切而细心的保护人; 你自会听到大家都一致赞他是位体贴入微的最好哥哥”。(WANG, 2006, pp. 79-80)

Table 1

Inconsistent Renditions of "pride" in Dialogue 1

\begin{tabular}{|c|c|c|c|c|c|c|c|c|c|c|c|}
\hline & $\underline{1}$ & $\underline{2}$ & 3 & 4 & 5 & 6 & $\underline{7}$ & 8 & 9 & 10 & 11 \\
\hline W & 自尊心 & 骄傲 & 傲慢 & 傲慢 & 傲慢 & 傲慢 & 傲慢 & 骄傲 & $\circ$ & 骄傲 & 骄傲 \\
\hline Z \& Z & 高傲 & 高傲 & 傲慢 & 傲慢 & 傲慢 & 傲慢 & 傲慢 & 傲慢 & 骄傲 & 自豪 & 骄傲 \\
\hline $\mathrm{S}$ & 骄傲 & 骄傲 & 傲慢 & 傲慢 & 傲慢 & 傲慢 & 傲慢 & 自尊 & 自尊 & 引以为豪 & 自尊 \\
\hline $\mathrm{F}$ & 傲慢 & 傲慢 & 傲慢 & 傲慢 & 傲慢 & 傲慢 & 傲慢 & ○ & ○ & 傲慢 & 自尊 \\
\hline L & 自尊心 & 骄傲 & 傲慢 & 傲慢 & 傲慢 & 傲慢 & 傲慢 & 骄傲 & $\circ$ & 骄傲 & 骄傲 \\
\hline D & 傲慢 & 傲慢 & 骄傲 & 骄傲 & ○ & 傲慢 & 傲慢 & 骄傲 & ○ & 为荣 & 骄傲 \\
\hline$L \& D$ & 骄傲 & 骄傲 & 骄傲 & 骄傲 & $\circ$ & ○ & 骄傲 & 骄傲 & 骄傲 & $\circ$ & 骄傲 \\
\hline
\end{tabular}

Dialogue 2 and its Chinese rendition are as follows.

"I do not believe a word of it, my dear. If he had been so very agreeable, he would have talked to Mrs. Long. But I can guess how it was; everybody says that he is ate up with pride ${ }^{1}$, and I dare say he had heard somehow that Mrs. Long does not keep a carriage, and had come to the ball in a hack chaise"

"His pride" ", said Miss Lucas, "does not offend me so much as pride often does, because there is an excuse for it. One cannot wonder that so very fine a young man, with family, fortune, everything in his favour, should think highly of himself $^{3}$. If I may so express it, he has a right to be proud ${ }^{4} "$.

"That is very true", replied Elizabeth, "and I could easily forgive his pride ${ }^{5}$, if he had not mortified mine ${ }^{6,}$.

"Pride 7 ", observed Mary, who piqued herself upon the solidity of her reflections, "is a very common failing I believe. By all that I have ever read, I am convinced that it is very common indeed, that human nature is particularly prone to it, and that there are very few of us who do not cherish a feeling of self-complacency on the score of some quality or other, real or imaginary. Vanity and pride are different things, though the words are often used synonymously. A person may be proud $^{8}$ without being vain. Pride ${ }^{9}$ relates more to our opinion of ourselves, vanity to what we would have others think of us".

"If I were as rich as Mr. Darcy", cried a young Lucas who came with his sisters, "I should not care how proud ${ }^{10} \mathrm{I} \mathrm{was.}$ I would keep a pack of foxhounds, and drink a bottle of wine every day”. (Austen, 2003, p. 21)

“亲爱的, 你刚说的我一个字都不信。如果他真这么讨人喜欢, 他应该会去和隆格太太说话。但我能猜到是什 么情形; 每个人都说他骄傲 ${ }^{1}$ 得不得了, 我敢说他多少有听到隆格太太没坐自己马车去, 而是临时雇了一辆赶去”。

“他的傲慢”, 庐卡斯小姐说, “并不像一般情形一样冒犯到我。这样一位有着好家室, 财富且样样条件都胜过别 人的优秀年轻人, 也难怪要自视甚高 ${ }^{3}$ 。我觉得他有骄橵 ${ }^{4}$ 的权利”。“那倒是真的”, 伊丽莎白说, “而且我很容易就 原谅他的傲慢 5 , 如果他没损及我就好”。

“傲慢”, 玛丽评论着, 她觉得自己的见解扎实而提高了兴致, “我相信是一般人的通病。就我读过的资料看来, 我确信它真的很普通。人性真的很容易向它屈服, 只有少数人不会因具有某种真实或相像的特质而不去珍惜那种自 
我满足的感觉。虚荣和傲慢是两件不同的事, 虽然这两个字常被视作一样的意思。一个人可以高傲而不自负。傲 慢比较是我们对自己的看法, 自负则是我们在他人心中的印象”。

“如果我像达西先生一样富有”, 庐卡斯小姐年轻的弟弟蠔道, “我才不会在意自己多骄傲10。我会养一堆猎犬, 而且一天喝一瓶酒”。(LIU \& DENG, 2006, pp. 19-20)

Table 2

Inconsistent Renditions of "pride" in Dialogue 2

\begin{tabular}{|c|c|c|c|c|c|c|c|c|c|c|}
\hline & 1 & $\underline{2}$ & $\underline{3}$ & $\underline{4}$ & 5 & 6 & 7 & 8 & 9 & 10 \\
\hline $\mathrm{W}$ & 骄傲 & 骄傲 & 自以为了不起 & 骄傲 & 骄傲 & 骄傲 & 骄傲 & 骄傲 & 骄傲 & 骄傲 \\
\hline$Z \& Z$ & 傲慢 & 骄傲 & 过高估计自己 & 骄傲 & 傲气 & 傲气 & 骄傲 & 骄傲 & 骄傲 & 骄傲 \\
\hline $\mathrm{S}$ & 傲慢 & 骄傲 & 自以为了不起 & 骄傲 & 骄傲 & 自尊心 & 骄傲 & 骄傲 & 骄傲 & 骄傲 \\
\hline $\mathrm{F}$ & 傲慢 & 傲慢 & 自以为了不起 & 摆摆架子 & 傲慢 & 尊严 & 傲慢 & 傲慢 & 傲慢 & 傲慢 \\
\hline $\mathrm{L}$ & 骄傲 & 骄傲 & 自以为了不起 & 骄傲 & 骄傲 & 骄傲 & 骄傲 & 骄傲 & 骄傲 & 骄傲 \\
\hline $\mathrm{D}$ & 自高自大 & 傲慢 & 骄傲 & 自豪 & 傲慢 & 自尊 & 高傲 & 高傲 & 高傲 & 傲慢 \\
\hline$L \& D$ & 骄傲 & 傲慢 & 自视甚高 & 骄傲 & 傲慢 & $\circ$ & 傲慢 & 高傲 & 傲慢 & 骄傲 \\
\hline
\end{tabular}

\section{Analysis of the Wrong Renderings of "pride"}

As can be seen from the two instances presented above, "pride" is rendered as five Chinese words. 傲慢, 高傲, 骄傲, 自尊, and 尊严. Before analyzing the mistakes in the Chinese renditions, it is necessary to examine the different connotations of these five Chinese words. These words can be used either as a noun or adjective and range from being derogatory to neutral and to commendatory: 傲慢 (insolence), 高傲 (arrogant/proud loneliness/proud and dignified bearing), 骄傲 (pride), 自尊 (self-respect), and 尊严 (dignity). 傲慢 is a strong critique that refers to a person's overbearing and disrespectful attitude or behavior. It often occurs in expressions like 傲慢自大 and 傲慢无礼. 高傲, as well as 骄傲, has flexible connotations. Very often 高傲 carries a derogatory connotation except on a few occasions. When used to describe a woman 高傲 can be neutral or commendatory and always commendatory when used to refer to 梅花 (plum blossom) or used figuratively as in “高傲的头领, 自豪的脊梁”. 自尊 and 尊严 have commendatory connotations.

\section{Consequences of the Wrong Renderings of "pride"}

The different renderings of "pride" in both of the two dialogues create problems. The main problem lies in Chinese reader's mistaken yet justifiable impression that the characters are either taking about different things or constantly correcting themselves or one another. In the original novel, however, these characters are engaged in smooth and coherent conversations. In dialogue 1, "pride" is repeated 10 times if its adjective form and pronoun form also count. Clearly the repetition of "pride" fulfils the function of keeping the dialogue cohesive and coherent. Readers of the English version of the novel can easily see that Elizabeth and Wickham are talking about the same thing: Darcy's pride. In WANG's Chinese version, however, Elizabeth shifts from the commendatory 自尊心 to the neutral/slightly derogatory 骄傲 and then to the derogatory 傲慢 while Wickham shifts from 傲慢 to 骄傲. Similar mistakes occur in all of the seven Chinese versions except in LIU and DENG's version, where "pride" is rendered as 骄傲 almost all the way through the conversation . In LIU and DENG's rendition of dialogue 2, however, "pride" is unfortunately rendered as several different Chinese words. This proves that the renditions by LIU and DENG are not governed by a clear understanding of the word "pride" or its cohesive function. The same is true with the renditions of WANG and LE. In dialogue 2 
"pride" is rendered by these two translators into 骄傲 all the way through, whereas in their renditions of dialogue 1 "pride" is rendered as several different Chinese words.

Another problem arises when a simple comment by a character of the novel is made totally illogical and ridiculous owing to the wrong rendering of "pride". This problem is best exemplified in the disastrous rendering of Wickham's comment “It (pride) has connected him nearer with virtue” into “傲慢使他比较注重 道德” (insolence has connected him nearer with virtue) in five of the seven Chinese versions examined in the paper. What is equally unacceptable is that this comment is simply ignored and deleted in the other two Chinese versions. A less common mistake is found in the rendering of Mary's comment "Pride relates more to our opinion of ourselves". This comment is rendered as “傲慢比较是我们对自己的看法” (insolence relates more to our opinion of ourselves) in two of the seven renditions of dialogue 2, whereas it is obvious that 傲慢 是别人对我们的看法 (insolence relates to how others look at us).

\section{Possible Reasons Behind the Wrong Renderings of "pride"}

There are three possible reasons behind the wrong renderings of "pride" in the seven Chinese versions of the novel. Firstly, Chinese translators failed to obtain an insightful interpretation of Darcy's pride and thus their renderings blur the distinction between Darcy's pride and his aunt's "arrogance", "conceit", or "insolence" (to quote Wickham). In fact, Darcy's pride has two parts. Outwardly his haughty manners can be "repulsive" (to quote Elizabeth, "proud and repulsive as were his manners") to other people while inwardly his pride relates more to his opinion of himself. According to Mary, "Pride relates more to our opinion of ourselves, vanity to what we would have others think of us". Darcy's repulsively proud manners partly originate from his inner pride in his "family, fortune and everything in his favour" (to quote Miss Lucas). While it may be theoretically acceptable to translate "pride" as 傲慢 when the external part of Darcy's pride is talked of, problems arise when the inner part is referred to as in "pride has connected him nearer with virtue". Darcy's inner pride is mentioned on many other occasions in the novel. In Chapter 10, volume 2 of the novel, for example, Elizabeth attributes her sister's hopeless romance to Darcy's inner pride. The renderings of "pride" in this example are shown in Table 3.

When she thought of her mother, indeed, her confidence gave way a little, but she would not allow that any objections there had material weight with Mr. Darcy, whose pride ${ }^{1}$, she was convinced, would receive a deeper wound from the want of importance in his friend's connections, than from their want of sense; and she was quite decided at last, that he had been partly governed by this worst kind of pride ${ }^{2}$, and partly by the wish of retaining Mr. Bingley for his sister. (Austen, 2003, p. 144)

Table 3

Renditions of Darcy's Inner Pride

\begin{tabular}{|c|c|c|c|c|c|c|c|}
\hline & $\mathrm{W}$ & $Z \& Z$ & $\mathrm{~S}$ & $\mathrm{~F}$ & $\mathrm{~L}$ & $\mathrm{D}$ & $L \& D$ \\
\hline pride $^{1}$ & 自尊心 & 自尊心 & 自尊 & 自尊心 & 自尊心 & $\begin{array}{l}\text { 傲慢 } \\
\end{array}$ & 骄傲 \\
\hline pride ${ }^{2}$ & 傲慢 & 傲慢 & 傲慢 & 傲慢 & 自尊心 & 傲慢 & 骄傲 \\
\hline
\end{tabular}

Darcy's pride is different from that of Lady Catherine, his aunt. It is true that Darcy's pride does sometimes escalate to reach haughtiness in the eyes of the omniscient narrator (see page 18 of the novel where Darcy is said to be "haughty, reserved and fastidious") and insolence in the eyes of Elizabeth (see page 155 where the style of his letter is "all pride and insolence"). For the Hertfordshire residents, however, Darcy is most of the time proud rather than arrogant, conceited, or insolent. The pride of "well-bred" and "clever" Darcy 
is somewhat justified and regulated when compared with that of Lady Catherine. However, the renderings of translators may lead to the wrong interpretation of the character traits of Darcy on the part of the Chinese reader. The following two examples are taken from Chapter 16 of volume 1 and Chapter 14 of volume 3 of the novel. The renderings of Lady Catherine's character traits in these two examples are shown in Table 4.

"Mr. Collins", said she, "speaks highly both of Lady Catherine and her daughter; but from some particulars that he has related of her ladyship, I suspect his gratitude misleads him, and that in spite of her being his patroness, she is an arrogant, conceited woman".

"I believe her to be both in a great degree", replied Wickham; "I have not seen her for many years, but I very well

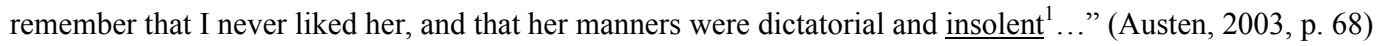

Her carriage remained at the door, and Elizabeth saw that her waiting-woman was in it. They proceeded in silence along the gravel walk that led to the copse; Elizabeth was determined to make no effort for conversation with a woman who was now more than usually insolent ${ }^{2}$ and disagreeable.

"How could I ever think her like her nephew?" said she, as she looked in her face. (Austen, 2003, p. 259)

Table 4

Renditons of Lady Catherine's Personality

\begin{tabular}{llllllll}
\hline & $\mathrm{W}$ & $\mathrm{Z} \& \mathrm{Z}$ & $\mathrm{S}$ & $\mathrm{F}$ & $\mathrm{L}$ & $\mathrm{D}$ & $\mathrm{L} \& \mathrm{D}$ \\
\hline arrogant & 狂妄 & 狂妄自大 & 高傲 & 高傲 & 清高 & 妄自尊大 & 傲慢 \\
conceited & 自大 & 目空一切 & 自负 & 自负 & 自负 & 目空一切 & 自负 \\
insolent $^{2}$ & 傲慢 & 专横无理 & 傲慢 & 傲慢 & 傲慢无礼 & 盛气凌人 & 傲慢无礼 \\
\hline
\end{tabular}

The word "pride" carries a much less derogatory connotation than "arrogant", "conceited", or "insolent". However, in the examples above these words tend to become all mixed up and indistinguishable in the Chinese versions. In five of the seven Chinese versions “insolent” is rendered as 傲慢 or 傲慢无礼. In three of the seven Chinese versions “arrogant” is rendered as 高傲 or 清高, which are less derogatory than 傲慢 used by the translators to refer to Darcy's pride.

Secondly, the Chinese title of the novel may have served as a blindfold, rendering the translators oblivious of their mistakes. It is obvious that the closest Chinese equivalent of "pride" is 骄傲 and that the easiest way to deal with "pride" is to replace it with its closest Chinese equivalent and then stick to 骄傲 all the way through the novel, but the translators did not take the easiest way. The possible reason is that the translators liked the Chinese title 傲慢与偏见 (Wang Ke-yi was the first one who came up with this title.) too much to let go of it. In the Chinese title 傲慢 rhymes nicely with 偏见, creating a similar effect to that of the alliteration with the letter P. In addition, 傲慢 creates a vivid image of the sometimes haughty Darcy. Though looking perfect, the Chinese title, together with an incorrect understanding of Darcy's pride on the translators' part, leads to various mistakes. Generally speaking, the title of a novel can highlight its theme and serve as the core around which other parts of the novel revolve. Theoretically once it is decided that "pride" in the title should be 傲慢, translators need to stick to 傲慢 every time "pride" occurs. FANG's renditions of the two dialogues stick to 傲慢 15 out of 20 times even when the contexts do not permit 傲慢. In the renditions of other translators 傲慢 is sometimes replaced with a close or remote synonym when the contexts call for a replacement, but as soon as the contexts become less demanding, 傲慢 comes back. This transition is most evident in ZHANG and ZHANG's rendition of dialogue 1 and in the renditions of the sentence where Elizabeth attributes her sister's hopeless romance to Darcy's pride. 
Thirdly, translators of the novel were not fully aware of the coherent and narrative functions of the repetition of "pride". Pride is one of the most important themes in the novel. It is a character trait possessed not only by Darcy but also by Collins and Elizabeth. It can also refer to something positive. In the eyes of the reader, for example, Elizabeth's proud and impertinent manners depicted by Miss Bingley are an indication of her self-respect. The word "pride" carries a commendatory connotation in Elizabeth's comment "they may wish him to marry a girl who has all the importance of money, great connections, and pride". The repetition of "pride" in the two dialogues and other places of the novel builds up and highlights this theme, which is undermined by the renderings of "pride" as 傲慢 in the title and 高傲, 骄傲, 自尊, or 尊严 in the chapters of the novel. Additionally, while it is true that "pride" may carry slightly different connotations for different characters in dialogue 1 and dialogue 2, this does not mean that translators shall make constant adjustments so that the renderings of "pride" conform to the characters' different attitudes towards Darcy. ZHOU Tian is wrong in believing that "pride" shall be rendered as the derogatory 傲慢 when uttered by Mrs. Bennet and the neutral 骄傲 when uttered by Miss Lucas. Unfortunately, ZHOU's proposition seems to be shared in the renditions of dialogue 1 by ZHANG and ZHANG, and Sun Zhi-li, where "pride" sticks to 骄傲 almost all the way through except when uttered by Mrs. Bennet, who holds a grudge against Darcy more than anybody else. If the coherent and narrative functions of repetition are undermined in the renderings of ZHANG and ZHANG, and SUN for a reason, the rendering of “pride" uttered by Miss Lucas as 傲慢 by DONG, and LIU and DENG is more unacceptable. It needs to be added that the translators were not totally unaware of the coherent and narrative functions of repetition. All of them except LIU and DENG, for instance, stuck to the same rendering of "pride" in Mary's comment in dialogue 2. FANG's renditions of the two dialogues stick to 傲慢 15 out of 20 times even when contexts do not permit 傲慢.

\section{My Suggestion}

Based on the above analysis, it can be suggested that "pride" be rendered as 骄傲 all the way through the whole novel. One possible alternative to 骄傲 is 高傲, which, like 骄傲, carries flexible connotations. Additionally, 高傲 foregrounds the image of a repulsively proud Darcy better than 骄傲 in the title of the novel. However, 高傲 is not so good as 骄傲 when we look at the whole picture. Firstly, 高傲 refers more to the external side than to the inner side of one's pride. Secondly, 高傲 is a derogatory word on most occasions. So problems will arise when "brotherly pride" is rendered as “身为兄长的高傲” or when “Pride relates more to our opinion of ourselves” is rendered as “高傲多指我们对自己的看法”.

\section{Conclusion}

Repetition plays a very important role in keeping a text cohesive and coherent. The word "pride" is repeated a great number of times in the novel Pride and Prejudice. The easiest way to deal with "pride" is to stick to 骄傲 all the way through the novel, but was disserted by all the seven translators examined in this paper. In the two significant dialogues examined in the paper the same word is rendered differently in each of the seven Chinese versions of the novel. As a result, the cohesive and coherent discourses in the original novel are ruined and the Chinese reader may get a wrong impression of the character traits of Darcy. The paper points out three possible reasons behind the wrong renderings. It is therefore hoped that the paper will shed light both on the translation of Pride and Prejudice and on the functions and translation of repeated words in other novels. 


\section{References}

Anderson, C. (1994). Matthew's narrative web: Over, and over, and over again. Sheffield: JSOT Press.

Austen, J. (2003). Pride and prejudice. London: Planet Three Publishing Network Ltd..

DONG, L. (Trans.). (2007). Pride and prejudice. Taipei: Crown Publishing Company Ltd..

FANG, H. W. (Trans.). (2011). Pride and prejudice. Nanjing: Yilin Publishing House.

Halliday, M., \& Hasan, R. (Trans.). (2007). Cohesion in English. Beijing: Foreign Language Teaching and Research Press.

HU, Z. L. (1984). Discourse cohesion and coherence. Shanghai: Shanghai Foreign Language Education Press.

JING, S. R. (2001). On the English-Chinese translation of repetition of rhetoric words in a discourse: A case study of four Chinese versions of innovations. Paper read at The Ninth National Symposium of China Association for Comparative Studies of English and Chinese.

Kirby, J. (2009). Repetition in the book of revelation (Doctoral dissertation, The Catholic University of America).

LE, X. (Trans.). (2011). Pride and prejudice. Taipei: The Commercial Press Ltd..

LIU, P. F., \& DENG, S. M. (Trans.). (2009). Pride and prejudice. Taichung: How Do Publishing Co., Ltd..

SUN, Z. L. (Trans.). (1999). Pride and prejudice. Nanjing: Yilin Publishing House.

WANG, K.Y. (Trans.). (2006). Pride and prejudice. Shanghai: Shanghai Translation Publishing House.

ZHANG, D. L., \& LIU, R. S. (2003). The development of the theory of text cohesion and coherence and its applications. Shanghai: Shanghai Foreign Language Education Press.

ZHANG, L., \& ZHANG, Y. (Trans.). (2004). Pride and prejudice. Beijing: People's Literature Publishing House.

ZHOU, T. (2007). Coherence in literary translation: A case study of the Chinese versions of Pride and Prejudice. Journal of Changsha University, 21, 101.

ZHU, Y. S., ZHENG, L. X., \& MIAO, X. W. (2001). A contrastive study of cohesion in English and Chinese. Shanghai: Shanghai Foreign Language Education Press. 